\title{
Rehabilitation doxa and practitioner judgment. An analysis of symbolic violence on health care provision in the Scottish prison system
}

\author{
Doxa da rehabilitação e o julgamento professional. \\ Uma análise da violência simbólica na provisão de cuidados \\ em saúde no sistema prisional escocês
}

Fernando Lannes Fernandes ${ }^{1}$

Ann Swinney ${ }^{1}$

Scott McMillan ${ }^{1}$

Dean MacLeay ${ }^{1}$

John McGhee ${ }^{1}$

William Graham ${ }^{2}$

Gary Roberts ${ }^{1}$

\footnotetext{
${ }^{1}$ Peripheries Research Group, School of Education and Social Work, University of Dundee. Nethergate. DD1 4HN Dundee Scotland UK.

f.l.fernandes@dundee.ac.uk ${ }^{2}$ Department of Sociology, School of Social \& Health Sciences, University of Abertay. Dundee Scotland UK.
}

\begin{abstract}
This paper presents an analysis of the symbolic conditions which govern health care provision in the Scottish prison system. The paper considers the wider context of Scottish prisons, where health care provision follows a similar structure both in juvenile and adult prisons. Our intention is to provoke a debate about the doxa (Bourdieu, 1977), which underlies decision making in respect of health care in prison, in a political environment where pragmatism, allied to the 'pathologisation' of social policies, health and criminal justice has been a hegemonic force.
\end{abstract}

Key words Bourdieu, Doxa, Symbolic violence, Prison, Scotland
Resumo Este artigo apresenta uma análise das condições simbólicas que governam a provisão de saúde nos sistemas prisional escocês. O artigo considera o contexto ampliado do sistema prisonal escocês, onde a provisão de saúde segue uma estrutura similar tanto nas unidades juvenis quanto nas de adultos. Nossa intenção é provocar um debate sobre a doxa (Bourdieu, 1977) que sustenta as tomadas de decisão sobre provisão de saúde nas prisões, onde o contexto político marcado pelo pragmatismo, aliado à 'patologização' das politicas sociais, de saúde e de justiça criminal, tem sido uma força hegemônica.

Palavras-chave Bourdieu, Doxa, Violência simbólica, Prisão, Escócia 


\section{Introduction}

While the Scottish Prison Service (SPS) as a whole has moved toward a more care orientated ethos in recent years under its new Organisation Review - Unlocking Potential, Transforming Lives launched in 2013, with a focus on the rehabilitation of returning citizens, the Scottish Children's Hearing System (CHS) has, been from the outset, a welfare based initiative that places the welfare of the child as central. A noteworthy distinction between these two constructions of care is that under the rehabilitation rhetoric of adult prison, custody continues to be framed as the best place to access support and services for those in need, despite its damaging effects, where as a logic of diversion from custody and the use of imprisonment as a last resort in acknowledgement of its inherently damaging impact on those incarcerated, now underpins the principles of youth justice.

The Scottish prison system can, hold prisoners from the age of 12 (the minimum criminal age in Scotland) in extreme cases, although in practice, only those aged $16+$ are likely to be sentenced to detention in a young offenders institution (YOI). In Scotland the sentences for under 18 can be extended to adult life in cases of homicide or serious sexual assault. Until the age of 21, a person is held in a YOI, being then, transferred to an adult prison to complete the sentence. There is no substantial difference in the health provision between YOI and adult prisons, despite specific strategies adopted by the government to improve the overall outcomes of YOI. In November 2011 the responsibility for the provision of health care in Scottish prisons was taken over by the National Health Service Scotland (NHS Scotland). Previously, access to primary health care for prisoners, was the responsibility of the SPS. The transfer of responsibilities from SPS to NHS Scotland was triggered by the requirement that health services for prisoners should equate to those offered to the general population and that responsibility for healthcare across the whole population irrespective of status should be subsumed by the NHS.

The transfer was guided by four strategic objectives as follows: (i) Tackling 'health inequalities', considered a national challenge, particularly in respect of prisoners whose health indicators are worse than the general population; the need to (ii) meet accepted international standards. In particular the Principle 9 of the United Nation Basic Principles for the Treatment of Prisoners', and the Moscow Declaration on Prison Health as Part of Public Health ${ }^{2}$; (iii) The continuity of health care refers to the need to ensure proper planning and coordination when prisoners leave prison, in view of the high risk of suicide and recidivism. Finally, (iv) the need for sustainability in the provision of health services, as the quality of provision of health services offered by SPS was considered limited.

Our intention with this paper is to produce an analysis of the overall conditions in which health provision takes place in Scottish Prisons. We do not intend to analyse the health provision itself, or the health status of prisoners. Instead, we aim to produce an analysis of the drivers for policy and practitioner attitudes that in our view, are sustained by a rehabilitation doxa, which sees the prison setting as a privileged space for social and health intervention.

\section{The prison as a space \\ of medical intervention}

There is broad consensus that prison is a privileged space for medical intervention. This view suggests that prison offers a key opportunity for access to health care and goes some way towards addressing 'health inequalities'. Indeed, it is argued that interventions, which are not limited to health - in prisons, can favour groups whose social and health conditions are worse than that of the general population ${ }^{3-7}$.

In our opinion, this view is problematic because:

i. It focuses on prison as a potential space for medical intervention when, in fact, the prison is a place where mental health and other general health conditions may deteriorate due to incarceration itself ${ }^{8}$, with a particular concern when it comes to children and young people in custo$\mathrm{dy}^{9,10}$. Therefore, it seems reasonable to say that health intervention in prison is most likely to be ameliorative rather than a solution to prisoners' health problems. However, additionally, health intervention can also be used to support punitive measures, for example where drugs may be used to keep prisoners under control ${ }^{11}$.

There is a tendency to characterise the 'prison population' as a homogeneous mass, especially with regard to its relationship with what is widely defined, understood and socially represented as a 'healthy lifestyle'. This characterization reveals a systematic process of symbolic violence in which certain assumptions and beliefs about the prison population are reproduced and perpetuated in what is an expanded system of punishment ${ }^{12}$. 
In this paper, we want to focus on this second problem, relating to the doxa - taken for granted and naturalised ideas, beliefs, representations that sustain decision making and practitioner attitudes towards health provision in prison ${ }^{13}$. Our point is to understand what constitutes the rehabilitation doxa, and how this reproduces a broader punitive system that is targeted on specific groups in society. We argue that health policies and health interventions in the prison system, which are oriented by a neo-rehabilitative ideal ${ }^{14,15}$, can act to legitimise and reproduce a neoliberal welfare doxa ${ }^{16}$, in which a wider process of the penalisation of poverty has been deployed as part of structural changes to the welfare system in the UK. As such, the naturalization of given notions and social representations about the prison population have contributed to generate a new commonsense that is oriented by the need to address and 'fix' the 'degenerative' nature of prison population lifestyle, which is believed to interfere with health outcomes.

We maintain that such commonsense became the consensus across the political spectrum over the past decades, reinforced by the strong influence of the evidence-based movement (EBM) in policy-making ${ }^{17,18}$. We argue that EBM contributed to reinforce the neoliberal doxa by generating the 'unquestionable' truth that confirms statistical correlations on the link between poverty and 'health inequalities', between negative 'health behaviour/literacy' and poor health outcomes notions that are at the heart of what Clarke and Newman ${ }^{19}$ called the 'alchemy of austerity' - the process in which structural social problems are transformed into problems of welfare dependen- cy, a culture of entitlement and irresponsibility. This complex and blinkered system constitutes a conjunction of what Foucault conceptualised as 'regime of truth' (the EBM model) ${ }^{20}$ and what Bourdieu called 'doxa' (the set of beliefs and representations that generate commonsense, which in our case, relates to the convergence of behaviour change, rehabilitation, and health intervention) (Figure 1).

The prison population, from this perspective, comprises those who, while in the community, are believed not capable of following a healthy lifestyle. In addition to this, the notions of poor 'health literacy' and 'chaotic life-style' reinforce the idea that certain individual's behaviour require control to generate better health outcomes. In our view, these arguments are problematic, because they sustain intervention policy focussed on changing individual behaviour, which is based on a premise of individual responsibility with little regard for the apparently intractable structural problems. We recognise the pivotal nature of individual agency in the change process, but we argue that the current atomised interventions and populist driven political agenda detracts from, indeed obliterates, the intractable structural problems and instead blames individuals, increases social disgust and, ultimately, justifies punitive measures in welfare policies.

The current policy and practice in Scotland, suggests a political position in relation to incarceration, which is sustained by the belief that prison provides a window of opportunity for treatment and social support ${ }^{21,22}$. This takes place in a context where decisions on involuntary clients' service engagement are governed by

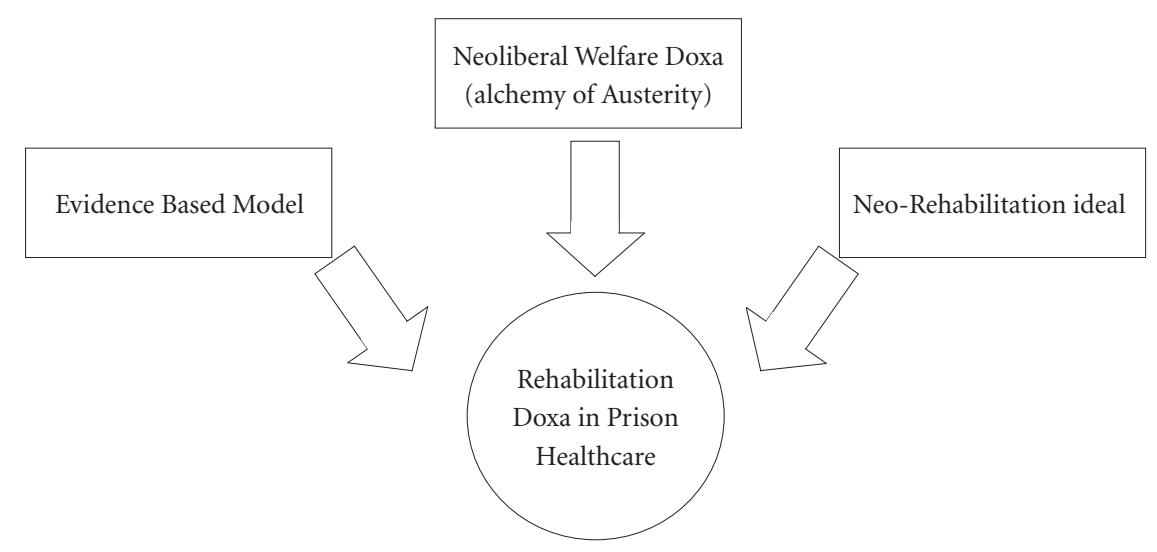

Figure 1. The rehabilitation doxa in prison healthcare. 
subtle mechanisms of social control and discipline that are ultimately framed by the nuances and forms of governance existing in the prison environment. The argument that this population does not follow treatment when out of jail is reinforced by the idea, often supported by a moral judgment, that when prisoners are in the community, they have a 'chaotic lifestyle' and, therefore, do not meet the practical conditions of access to health services and medical treatment. As illustrated by our own research, the access to health and other social services is not always a matter of individual competency, but rather, a complex interaction between stigma, prejudice and symbolic power that governs the attitudes of service providers and service set $u^{23}$.

\section{The Scottish prison system and the dynamics of imprisonment}

In our view, it is not possible to understand the Scottish Prison system without an understanding of the conditions in which socio-symbolic annihilation operates in Scottish, and more widely, British society, especially those mechanisms that operate for the 'monsterisation' of certain groups. Furthermore, it is necessary to consider the processes in which marginalised groups are 'pushed' to the prison system, or in a wider sense, into an expanded punitive system, which has the prison as its most extreme example. In this way, although access to health is a right that should be offered to every prisoner, its implementation can, eventually, also operate as a normative mechanism that aligns with a punitive regime. For that reason, it is necessary to investigate the assumptions that underlie health care discourse and practice in prison.

The dynamics of imprisonment in Scotland are apparently contradictory. While the number of under 21s in custody decreased over the past decade, an opposite trend was observed in the adult prison population. One component that adds complexity to this is the fact that while the adult population increased, the number of criminal records registered by the police declined for the same period. Scotland has one of the higher incarceration rates in Western Europe (140 per $100,000)$. Currently, there are 7,472 prisoners, from which $4.5 \%$ (339) are young people aged between 16-20 in custody ${ }^{24}$.

Two UK-wide socio-political processes are central to understanding the dynamics of incarceration and, in a way, the penalisation of vulnerable social groups. First, the advent of the
Anti-Social Behaviour Act 2003 played a central role in the penalisation of poverty in the United Kingdom as a whole by shaping new forms of regulating public conduct ${ }^{25}$, with the criminalization of non-criminal acts, and emphasis on individual behaviour $^{26,27}$. Arguably, this paradigm contributed to the pathologising of social deviation as part of a trend towards moral behaviourism in the convergence between social policies and criminal justice ${ }^{26}$ that gained force, in particular, among young people, under the stigmatising labelling of $N E D$, which in Scotland refers to hooligans, louts, petty criminals as well as, in a more recent fashion, to those Non-Educated Delinquent.

The second socio-political process refers to the toughening of neoliberal policies in the reshaping of social welfare, which had as its epicentre, social benefits reform proposed by the coalition Government led by Conservative Prime-Minister, David Cameron (2010-2016) and later taken on by his successor Theresa May. The driver for the reform of the social security system is the reduction of spending, with the adoption of measures that restricted access to benefits. The increased precariousness of the social welfare State has accentuated the level of pressure on historically vulnerable groups. More than that, the idea of 'deserving poor', in contrast to 'non-deserving poor', has gained traction. In this context, a punitive approach, with the adoption of moral behaviourism has resulted in the hardening of the conditional rules for those receiving state benefits. This has resulted in an increasingly punitive process with the use of harsh sanctions with the intention to induce 'responsible behaviour'.

The prison population in Scotland, and widely in the UK, fundamentally comprises those who are considered 'undeserving poor'. These are people who, according to the hegemonic conservative discourse, are not only incapable of managing their own lives and making the right choices, but also those who are, as a result of that, consciously making the 'wrong' choices - whether it be living on benefits, engaging in crime, or 'refusing to work'. All these explanations inform a 'pedagogy of monsterisation ${ }^{28}$ which produces a narrative of disposal and social disgust. With effect, the doxa starts with a mix of empirical evidence and further generalisations and simplified narrative that reinforce the emphasis on individual choice and, by extension, the weight of individual decisions on a person's own socio-economic situation. As such, the term 'chaotic life' becomes the strongest element of doxa underlying the moral 
behavioural measures of the penalisation of the poor. A 'chaotic lifestyle' - no matter it is empirically evident or not, provides the ultimate justification for the rehabilitative agendas performed in prison and beyond. Here, it is not a matter of disagreeing with the role of individual agency on change, but rather, a matter of questioning the relevance of such labelling for the political agendas, and what they represent. As such, it is necessary to understand how such labelling unfolds in the British social context with the increasing precariousness of the welfare system and the penalisation of marginalised groups.

\section{Moral behaviourism and practitioner judgment}

We argue that the issues around personal responsibility and moral behaviourism, are sustained by principles of practitioner judgmentwhich, in many ways, reproduce to what Bourdieu referred, in the school system, as professorial judgment $t^{29}$. Central to judgment is the hexis corporelle, which refers to the set of properties associated with the body, in which class position is exteriorised. For example, accent as well as the kind of words used, the way these words are employed and body language - not to mention attitudes and 'behaviours' that may be considered nonconforming. Not only the body itself, but its general appearance, the hair style, the skin - or indeed the wearing of clothes, earrings, cords, and tattoos. All of these converge to make a specific construction of judgment that sets the social and symbolic value of a person. As a result, the discourse of 'chaotic life style' and individual behaviour needs to be analysed from the point of view of an expanded hexis corporelle, which as a system of beliefs and production of commonsense operates as a dialogical interrelation between structural drivers and practitioner attitudes, or in other words, in between neoliberal doxa and rehabilitation doxa.

The neoliberal doxa functions as ideological basis of the rehabilitation doxa. One of the main symbolic components of the reform of the welfare state in the United Kingdom refers to the idea of 'broken society' or 'broken Britain'. 'Broken society' discourse sustains an explanatory narrative of poverty focused on a failure of individuals and families, whose way of life is presented as a predominant factor for their socio-economic status. Indeed, in addition to diverting public attention from the structural problems and institutional failures that underpin poverty, this discourse fu- elled a conservative wave that reinforced the idea of 'undeserving poor' in the political scen $e^{30}$, with the emergence of 'poverty-porn' which became a strategy to establish new forms of commonsense that operates to provoke public hatred, indignation and social disgust ${ }^{31-33}$. In poverty-porn TV shows such as Benefits Street (Channel 4, 2014), people are portrayed as human waste, being devoid of any dignity and value. Furthermore, 'poverty-porn' has the symbolic function of generating a new commonsense that justifies and authorises an unquestionable need for welfare reform. This can be conceptually framed in terms of a 'neoliberal doxa' ${ }^{34}$.

It is noteworthy that in recent years there has been an increase in'poverty-prison', with programmes such as Ross Kemp inside Barlinnie, First and last 24 hours, Boys Behind Bars, and Lifers; Life behind bars. This prison brand of 'poverty-porn' then, further perpetuates the cycle of sensationalism and public outrage by reinforcing the neoliberal doxa and the claim for an expanded punitive system.

Doxa as defined by Bourdieu ${ }^{13}$ corresponds to the 'taken for granted' set of beliefs, values, ideas and representations that sustain the habitus of a particular field. The Neoliberal doxa governmentality drives political decision-making and practices of public agents. In this sense, the incorporation of certain commonly accepted notions in the political spectrum, such as 'broken society', 'deserving/undeserving poor', assume an important role in decision-making. As Bourdieu argues, the way the practices operate in the social field are not necessarily conscious, but rather referenced by those notions that are, in fact, naturalized and embodied and therefore, unquestionable in the public discourse. We argue that these taken for granted assumptions operate in the wider socio-political spectrum as the foundation of policy making through to policy delivery, encompassing 'service provider' and 'service user' interactions.

The symbolic violence, in this context, corresponds to the set of practices and attitudes, which assume certain notions as natural, acts in a way so as to reinforce and reproduce social marginalisation. In fact, the problem of naturalization of the characteristics of the prison population, and their perpetuation in a wide punitive system is, fundamentally, a problem centred on the symbolic violence performed within this system. The condemnation of the dammed, therefore, refers to a perverse logic which reinforces the idea of a self-fulfilling prophecy. 
Within the prison system and its interface with the health care system, those references can be reflected by the doxa sustained in relation to prisoners. One of the central references sustaining rehabilitation doxa concerns the idea of 'chaotic lifestyle', a concept which emphasises the problems of an individual as resting, ultimately, on his/her ability to manage life, make the 'right choices' and make decisions that impact on one's own future.

The hardening of welfare conditionality and sanctions adopted by the UK social benefits system, is a central example for understanding the logic that underpins the symbolic violence among marginal groups, and which contributes decisively to their permanence in a wider punitive social system in which the prison appears to be the most extreme example. Sanctions have been widely used as a measure of punishment for those who do not conform to the rules of the system. The recourse to sanctions is aimed at punishing those who do not meet the rules of social benefit, but its effectiveness has been widely questioned $\mathrm{d}^{35,36}$.

Indeed, the criminalization of non-criminal acts has played a central role in the response to the increasing social insecurity in the UK. The focus on 'behaviour change' approaches that aim to address individual failure, has been widely used in social policy to punish those who will not fit or follow the rules and conditions imposed by the system. Refusal or failure to follow the rules often results in the intensification of welfare sanctions as well as the imposition of measures undertaken under the anti-social Behaviour Act. Indeed, the process of the 'condemnation of the damned' has been the norm in the dynamics of the criminalisation and penalisation of poverty in the United Kingdom $^{32,34,37}$.

If behaviour is taken as a premise in the process of change, we are talking about reproduction in the terms suggested by Bourdieu. Indeed, the emphasis on individual change processes can only result in the justification of such measures: the system knows the deficiencies and will operate to highlight such deficiencies in order to justify tougher actions against those who fail. Put simply, the process of demonization and 'pathologisation' of undesirable behaviour can see those in custody potentially spending months, years and even decades beyond the minimum sanction, not for the commission of further crimes, but for breaching prison regulations that specifically target health concerns and behaviours such as addiction and mental health, that are prevalent within the prison population ${ }^{38}$. Why then does the system insist on penalising instead of finding ways to ameliorate such failings? The parameters for behaviour change (like the parameters for educational attainment as investigated by Bourdieu) are almost unreachable for those who lack the habitus and capital needed for those changes. Prison is then a further case in point whereupon it knows the majority of those in its care suffer far greater instances of mental ill-health and drug addiction than the general population, yet criminalises and punishes disproportionately those who are unable to navigate the system without succumbing to the problems most prevalent within its population. Thus, despite its rehabilitation rhetoric, the prison acts more as a sifting system that punishes those most in need of support by keeping them in prison for longer, and claiming success for its efficacy in respect of those already in possession of the skills to navigate and adapt to the prison environment ${ }^{38}$. Furthermore, the only possible outcome is reinforcing the failure, and reproducing more failure.

The emphasis on prison as a space of intervention may be reinforcing a permanent process of penalizing the most marginalized groups, with the increasing trend towards imprisonment as a means of imposing a set of moral values and concomitant behaviour change. We can speculate with some level of confidence from practice, that the imperatives of the punishment regime are being explicitly used as a justification for decisions made in respect of individual's medical treatment. Although we know that in theory the choices about these treatments are for the individual prisoner to make, it is not unrealistic to assume power relations between staff and prisoner determine how and what treatment is sought. For example, in the report published by the Royal College of Nursing $^{39}$, health professionals reported that the decisions made by health practitioners, with regard to drug prescriptions, were being influenced by the prison staff, and there remains fear that information about patients was not being confidentially maintained. This situation illustrates the role of prison staff, and the power they have in relation to prisoners, for example, convincing them to follow a treatment that may result in the reduction/flexibility of sentence. Indeed, decisions with regard to health interventions appear to be subject to a complexity of factors and influences, which often blur the boundaries between the prisoner's legitimate right to access health services and the imperatives of the prison system. For example, access to programmes to address offending be- 
haviours have been identified as a lynch pin in prisoners' progression through the prison system (despite doubts about their efficacy), however access to these services are determined by prison psychology departments. This means those who do not meet the criteria for courses fall into grey areas and consequently experience undue scrutiny and barriers to progress, or are forced to manipulate a situation to ensure a referral (threatening to re-offend for example), such is the pivotal role of completing a programme in the 'tick box' culture which predominates.

\section{Final considerations}

The systems of belief and representations that drive healthcare provision in the prisons should be a matter of major investigation to understand the layers of symbolic violence operating both at policy making and practice levels. This is of relevance because, as we argue, even when policy and practitioners are well intentioned, it tends to reproduce inequalities and reinforce a wider punitive system. Indeed, if those working within the criminal justice system truly believe in rehabilitation and the ability of the prison to help/treat/ support an individual whilst in custody, then it is arguable that those specific agents have the best intentions. However, the fact is that they represent an institution that is both literally and symbolically synonymous with punishment. Deprivation of liberty, is the most severe punishment Scottish society can impose and yet, we find that the most liberal minded are championing prison as an ideal place for care and support. The primary role of prison as a place of punishment and control and the wider cultural discourse and negative construction of prisoners and the penal system, leave the most well-meaning and supportive care practitioners at a loss in an institution that is fundamentally at odds with the provision of effective and quality care provision.

Furthermore, there is a misinterpretation, and to some extent, naïve assumption, about the role of the prison as a rehabilitative setting. This has led to a seemingly healthy marriage between the prison system and health system. The challenges of integration between health and prison are manifold, as signalled in this paper, but if the assumptions that drive this integration are not reconsidered, we will reach a critical point where incarceration becomes a natural measure in response to problems that exacerbate the deprivation of freedom. Perhaps, following the Scandinavian model, that inspires Scottish politicians, the reduction of the prison population, with the adoption of alternative sentences, and extensive investment in social policies, should be considered. Unfortunately, what prison statistics show, suggest an opposite tendency, with the increase of imprisonment over recent years. Claimed improvements in the prison system, as such, do not translate to a radical change in the criminal justice landscape, but rather, the embedding of a trend towards an expanded system of punishment. This trend seems to be reproduced in every dimension of social policy as observed, in the current policy of welfare conditionality and sanctions. It is possible to argue that Scotland follows a different path from the rest of the UK, with fairer policies and greater concern for social justice as displayed in the rhetoric of the Scottish National Party (SNP) government. However, as we argue through the points raised in this paper, there are issues of a 'softer' nature that can jeopardize any substantial social change if not considered seriously in the political agenda. The persistence of the individualistic mind-set in policy-making and practitioner work, referenced by 'distracting' concepts such as 'resilience', 'self-esteem', 'health-literacy' -to give a few examples, are certainly at the heart of the commonsense, sustaining this symbolic war - which academic discourse has contributed to consolidate.

We are aware that symbolic violence, as Bourdieu argues, is very difficult to be challenged, as this is reproduced in a very embodied system of values and practices. However, as he suggests, 'to change the world one has to change the ways of world-making, that is the vision of the world and the practical operations by which groups are produced and reproduced ${ }^{40}$. Following that, we believe that any change in policy and practice regarding those who are affected by the broader punitive system in British society has to take the element of symbolic violence seriously, and consider the hidden and embodied forces that shape those policies and practices, and by extension, question and challenge the 'taken for granted' assumptions that orient the social representation and expectations of prisoners. 


\section{Collaborations}

All authors had equal participation in all stages
of paper.

\section{Acknowledgments}

We are grateful for Dr Sarah Armstrong's critical feedback and support.

\section{References}

1. United Nations (UN). Basic Principles for the Treatment of Prisoners : resolution / adopted by the General Assembly. Genève: UN General Assembly; 1991.

2. World Health Organization (WHO). Moscow Declaration on Prison Health as Part of Public Health. Geneva: WHO; 2003.

3. World Health Organization (WHO). WHO Regional Office for Europe. Prison and Health. Copenhague: WHO; 2014.

4. Scottish Government. Alternatives to Secure Care and Custody Guidance for Local Authorities, Community Planning Partnerships and Service Providers. Edinburgh: Scottish Government; 2011.

5. HMIPS, 'HM Chief Inspectorate of Prisons for Scotland: Annual Report 2015-2016, 2016. [cited 2017 Sep 15]. Available from https://www.prisonsinspectoratescotland.gov.uk/publications/hm-chief-inspector-prisons-scotland-annual-report-2015-2016

6. Scottish Drug Forum (SDF). Reduce re-offending with integrated approach to substance use and mental health issues in prisons. Glasgow: SDF; 2015.

7. Graham L. Prison Health in Scotland A Health Care Needs Assessment. 2007. [cited 2017 Sep 15]. Available from: http://www.ohrn.nhs.uk/resource/policy/ScottishPrisonHealthNeeds.pdf

8. Fazel S, Baillargeon J. The health of prisoners. Lancet 2011; 377(9769):956-965.

9. Youth Justice Improvement Board (YJIB). Children and Young People in Custody in Scotland: looking behind the data. Youth and Justice Improvement Board. 2017. [cited 2017 Sep 15]. Available from: http://www. cycj.org.uk/wp-content/uploads/2017/10/Young-People-in-Custody-October-2017.pdf

10. UNHCR, 2014. The Forgotten Children: National Inquiry into Children in Immigration Detention [cited 2017 Aug 12]. Available from: http://www.unhcr.org/ $\mathrm{uk} /$ protection/detention/54e70f8a9/forgotten-children-national-enquiry-children-immigration-detention-2014.html?query $=2014$

11. Costa NR, Silva PRF. Mental Health care for Brazilian juvenile offenders. Cien Saude Colet 2017; 22(5):14671478.

12. Bourdieu P. A distinção. Crítica social do julgamento. São Paulo: EdUSP/Zouk; 2006.

13. Bourdieu P. Outline of a Theory of Practice. Cambridge: Cambridge University Press; 1977.

14. Bell E. The new welfare sanction In: Bell E. Criminal Justice and Neoliberalism. London: Palgrave MacMillan; 2011. p. 62-92.

15. Morgan R. Just Prisons and Responsible Prisoners. In: Duff A, Marshall S, Dobash RE, Dobash RP, editors. Penal Theory and Practice: Tradition and innovation in criminal justice. Manchester: Manchester University Press; 1994.

16. Jensen T. Welfare commonsense, poverty porn and doxosophy. Sociological Research Online 2014; 19(3):3. 
17. Biesta G. Why 'what works' won't work: evidence-based practice and the democratic deficit educational research. Educational Theory 2007; 57(1):1-22.

18. Parsons W. From Muddling Through to Muddling Up - Evidence Based Policy Making and the Modernisation of British Government. Public Policy and Administration 2002; 17(3):43-60.

19. Clarke J, Newman J. The Alchemy of Austerity. Critical Social Policy 2012; 32(3):299-319.

20. Holmes D, Murray SJ, Perron A, Rail G. Deconstructing the evidence-based discourse in health sciences: truth, power and fascism. Int J Evid Based Healthc 2006; 4(3):180-186.

21. Scottish Prison Service (SPS). Vision for Young People in Custody: Report of the Scottish Prison Service Organisational Review. Edinburgh: SPS; 2014.

22. Scottish Prison Service (SPS). Unlocking Potential: Report of the Scottish Prison Service Organisational Review. Edinburgh: SPS; 2013

23. Fernandes FL, Sharp G. The situation of people who are at risk of homelessness in the city of Dundee. Dundee Drop In Survey. Final report. Dundee: University of Dundee; 2015.

24. Scottish Prison Service (SPS). Prison Population Spreadsheet. 2017. [cited 2017 Sep 28]. Available from: http://www.sps.gov.uk/nmsruntime/saveasdialog.aspx?IID $=3936 \& s I D=629$

25. Flint J, Nixon J. Governing Neighbours: Anti-social Behaviour Orders and New Forms of Regulating Conduct in the UK. Urban Studies 2005; 43(5/6):939-955.

26. Rodger J. Criminalising Social Policy. Anti-social behaviour and welfare in a de-civilised society. Devon: William Publishing; 2008.

27. Friedli L, Stearn R. Positive affect as coercive strategy: conditionality, activation and the role of psychology in UK government workfare programmes. Med Humanit 2015; 44(1):40-47.

28. Fernandes FL. For a pedagogy of coexistence in the polis. In: Shaw A, Bhattacharya A, editors. Housing, Livelihoods and Environmental Challenges in Urban India and Brazil. Telangana: Orient Blackswan; 2018.

29. Bourdieu P, Saint-Martin M. As categorias do juizo professoral. In: Nogueira MA, Caiani A, organizadores. Escritos de Educação. Petrópolis: Vozes; 1998. p. 185216.

30. Slater T. The Myth of "Broken Britain": Welfare Reform and the Production of Ignorance. Antipode 2012; 46(4):948-969.

31. Hancock L, Mooney G. "Welfare Ghettos" and the "Broken Society": Territorial Stigmatization in the Contemporary UK. Housing Theory and Practice 2013; 30(1):46-64.

32. Tyler I. Revolting Subjects. Social abjections and resistance in neoliberal Britain. London: Zed Books; 2013.

33. Mooney G. Stigmatising poverty? The 'Broken Society' and reflections on anti-welfarism in the UK today. Oxford: Oxfam; 2011.

34. Jensen T. Welfare Commonsense, Poverty Porn and Doxosophy. Sociological Research Online 2014. [cited 2017, Sep, 03] Available From: http://journals.sagepub. com/doi/pdf/10.5153/sro.3441

35. Watts B, Fitzpatrick S, Bramley G, Watkins D. Welfare sanctions and conditionality in the UK. How effective and ethical are conditional forms of welfare? York: John Rowntree Foundation; 2014.

36. Cowburn A. Suicides highlight the grim toll of benefits sanctions in austerity Britain. 2015. [cited 2017 Sep 6]. Available from: https://www.theguardian.com/ society/2015/jan/03/benefits-sanctions-leading-suicides-dwp-depression

37. Jones O. Chavs. The demonization of working class. London: Verso; 2012.

38. Scottish Prisoner Advocacy \& Research Collective (SPARC). Health Inequalities in Scottish Prisons. SPARC. 2016. [cited 2017 Sep 15]. Available from: https://scottishprisoneradvocacy.wordpress.com/2017/03/05/firstblog-post/

39. Royal College of Nursing (RCN). Five years on: RCN Scotland review of the transfer of prison healthcare from SPS to NHS Scotland. London: RCN; 2016.

40. Bourdieu P. Social Space and Symbolic Power. Sociological Theory 1989; 7(1):14-25.

Artigo apresentado em 08/10/2017

Aprovado em 26/02/2018

Versão final apresentada em 22/05/2018 
